\title{
Kajian Kesesuaian Wisata Selam dan Snorkeling di Perairan Tulamben, Karangasem, Bali
}

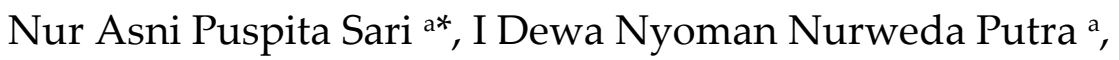 \\ I Gusti Ngurah Putra Dirgayusa a \\ a Program Studi Ilmu Kelautan, Fakultas Kelautan dan Perikanan, Universitas Udayana, Kampus UNUD Bukit Jimbaran, Bali 80361, Indonesia \\ * Penulis koresponden. Tel.: +62-85-728-785-103 \\ Alamat e-mail: puspitaasni@ymail.com
}

Diterima (received) 6 April 2017; disetujui (accepted) 4 Mei 2017; tersedia secara online (available online) 5 Mei 2017

\begin{abstract}
Tulamben village located in the district of Kubu, Karangasem regency, has developed into one of the maritime destination, especially diving and snorkeling. Based on data from the Department of Culture and Tourism of Bali, the average number of tourists coming to Tulamben in 2012-2014 reached 94,253 tourists. This condition makes the tourism has grown into a major economic support local communities in the Tulamben. Economic growth without being accompanied by an appropriate management plan will certainly produce a negative impact on coastal and marine resources to be a major asset for the growth. Various forms of management that allows to be applied has been identified in an effort to support the sustainability of the ecological, economic and socio-cultural community. This study was conducted to analyze the suitability of diving and snorkeling, coral identification were examined using LIT (Line Intercept Transect) methods while the abundance of reef fish species assessed using visual underwater cencus (UVC). Analysis of the data used is the analysis of the potential reef and suitability. Determination of the suitability of the area as a tourist diving and snorkeling analysis using matrix parameters to consider the appropriateness of the ecological conditions and water quality conditions of the four classifications. Cover of live coral communities ranged between $16.26 \%-52.48 \%$ with a diversity of reef fish species ranged between 11-44 types. Travel suitability index $(\mathrm{IKW})$ category snorkeling and diving are included in the category is not appropriate $(\mathrm{N})$ and the corresponding (S2).
\end{abstract}

Keywords: tourism suitability; diving; snorkeling; Tulamben

\begin{abstract}
Abstrak
Desa Tulamben yang berada di wilayah Kecamatan Kubu, Kabupaten Karangasem, telah berkembang menjadi salah satu destinasi wisata bahari khususnya wisata selam dan snorkeling di Pulau Dewata. Berdasarkan data dari Dinas Kebudayaan dan Pariwisata Provinsi Bali, rata-rata jumlah wisatawan yang datang ke Tulamben pada tahun 20122014 mencapai 94.253 wisatawan. Kondisi ini menjadikan pariwisata yang telah berkembang menjadi penunjang utama perekonomian masyarakat lokal di Desa Tulamben. Pertumbuhan ekonomi tanpa diiringi dengan rencana pengelolaan yang tepat tentunya akan menghasilkan dampak negatif terhadap sumberdaya pesisir dan laut yang menjadi aset utama bagi pertumbuhan tersebut. Berbagai bentuk pengelolaan yang memungkinkan untuk diterapkan telah diidentifikasi dalam upaya untuk mendukung keberlangsungan nilai ekologi, ekonomi dan sosial budaya masyarakat. Kajian ini dilakukan untuk menganalisis kesesuaian wisata selam dan snorkeling, identifikasi karang dikaji menggunakan metode LIT (Line Intercept Transect) sedangkan kelimpahan jenis ikan karang dikaji menggunakan metode underwater visual cencus (UVC). Analisis data yang digunakan adalah analisis potensi terumbu karang dan kesesuaian lahan. Penentuan tingkat kesesuaian kawasan sebagai kawasan wisata selam dan snorkeling menggunakan analisis matriks kesesuaian kawasan mempertimbangkan parameter kondisi ekologis dan kualitas perairan dengan empat klasifikasi. Tutupan komunitas karang hidup di Perairan Tulamben berkisar antara 16,26\% $52,48 \%$ dengan keragaman jenis ikan karang berkisar antara 11-44 jenis. Indeks kesesuaian wisata (IKW) kategori snorkeling dan selam termasuk dalam kategori tidak sesuai (N) dan sesuai (S2).
\end{abstract}

Kata Kunci: kesesuaian wiasata; selam; snorkeling; Perairan Tulamben 


\section{Pendahuluan}

Desa Tulamben yang berada di wilayah Kecamatan Kubu, Kabupaten Karangasem, telah berkembang menjadi salah satu destinasi wisata bahari utama khususnya wisata selam dan snorkeling di Pulau Bali. Melalui program Kajian Cepat Kondisi Kelautan Provinsi Bali (Marine rapid Assessment Program atau MRAP) yang dilaksanakan pada tahun 2011, kawasan perairan di sepanjang wilayah pesisir Kabupaten Karangasem diidentifikasi memiliki nilai konservasi yang tinggi. Kekayaan sumberdaya pesisir dan laut karangasem merupakan aset penting bagi pembangunan daerah yang pemanfaatannya didominasi oleh aktivitas perikanan tangkap maupun budidaya serta aktivitas pariwisata dan lalu lintas laut yang sangat bergantung kepada jasa lingkungan. Berdasarkan data dari Dinas Kebudayaan dan Pariwisata Provinsi Bali, rata-rata jumlah wisatawan yang datang ke Tulamben pada tahun 2012-2014 mencapai 94.253 wisatawan. Kondisi ini menjadikan pariwisata yang telah berkembang menjadi penunjang utama perekonomian masyarakat lokal di Desa Tulamben.

Pertumbuhan ekonomi tanpa diiringi dengan rencana pengelolaan yang tepat tentunya akan menghasilkan dampak negatif terhadap sumberdaya pesisir dan laut yang menjadi aset utama bagi pertumbuhan tersebut. Berbagai bentuk pengelolaan yang memungkinkan untuk diterapkan telah diidentifikasi dalam upaya untuk mendukung keberlangsungan nilai ekologi, ekonomi dan sosial budaya masyarakat. Bentuk pengelolaan tersebut diantaranya adalah sebagai kawasan strategis pariwisata, kawasan konservasi, cagar budaya bawah laut dan ekowisata. Diperlukan sebuah upaya kolaboratif dan terintegrasi untuk mendorong masing-masing inisiatif tersebut agar mampu menjawab tantangan pengelolaan kawasan di Tulamben yang mampu mendukung aktivitas pengembangan pariwisata dengan tetap memperhatikan kelestarian lingkungan. Sesuai dengan pernyataan Tomboelu et al. (2000) mengatakan bahwa dalam pengelolaan sumber daya terumbu karang untuk kegiatan wisata bahari harus adanya keseimbangan antara konservasi dan ekonomi, sehingga tidak terjadi konflik yang mengakibatkan kerusakan sumber daya terumbu karang.
Kegiatan pengembangan kawasan Perairan Tulamben sebagai tujuan utama wisata selam dan snorkeling yang dilakukan oleh pemerintah Kabupaten Karangasem tentu saja akan membutuhkan data dan informasi dalam pengembangannya agar kegiatan pariwisata yang dilakukan berjalan dengan baik dan tanpa merusak lingkungan. Data dan informasi yang dibutuhkan yakni data dan informasi tentang kondisi ekosistem terumbu karang dan kesesuaiannya untuk wisata selam dan snorkeling. Penelitian ini bertujuan untuk mengetahui kondisi ekosistem terumbu karang sebagai sumber daya laut dan pesisir Perairan Tulamben dan menganalisa kesesuaian wisata selam dan snorkeling di Perairan Tulamben

\section{Metode Penelitian}

\subsection{Waktu dan Tempat}

Penelitian ini dilaksanakan pada Bulan September 2016, di Perairan Desa Tulamben, Kabupaten Karangasem, Bali demgan batas panjang area sesuai dengan batas administratif wilayah Desa Tulamben. Pengambilan data dilakukan pada musim kemarau saat kondisi pasang. Karena adanya pelepasan energy gelombang di pantai hingga kedalaman 3 meter, maka pengambilan data dilakukan pada kedalaman 5 meter untuk kategori snorkeling dan 10 meter pada kategori selam.

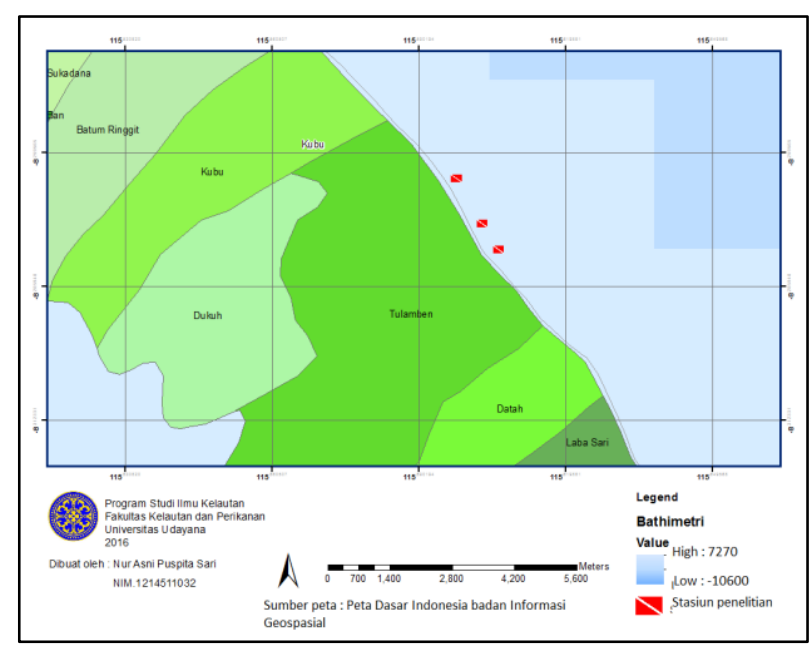

Gambar 1. Peta Lokasi Penelitian

Stasiun yang ditetapkan sebagai area pengamatan di Tulamben terdiri atas tiga stasiun 
masing-masing untuk kategori selam dan snorkeling. Stasiun 1 terletak di Shipwreck kedalaman 5 meter, stasiun 2 Shipwreck kedalaman 10 meter, stasiun 3 Coral Garden kedalaman 5 meter, stasiun 4 Coral Garden kedalaman 10 meter, stasiun 5 Drop Off kedalaman 5 meter, dan stasiun 6 Drop Off kedalaman 10 meter.

\subsection{Peralatan}

Peralatan yang digunakan dalam penelitian ini yaitu peralatan SCUBA dan alat ukur parameter kualitas lingkungan perairan (Tabel 1).

\section{Tabel 1}

Peralatan yang digunakan dalam penelitian

\begin{tabular}{ll}
\hline \multicolumn{1}{c}{ Alat } & \multicolumn{1}{c}{ Kegunaan } \\
\hline SCUBA equipment & Menyelam \\
Roll meter & Membuat garis transek \\
Alat tulis bawah air & Mencatat data \\
Underwater camera & Mendokumentasikan kegiatan \\
GPS & Menentukan koordinat lokasi \\
Buku identifikasi & Mengidentifikasi data ikan yang \\
ikan & diperoleh \\
Drift float & Mengukur kecepatan arus \\
Secchi disc & Mengukur kecerahan perairan \\
Dive computer & Mengukur kedalaman perairan \\
\hline
\end{tabular}

\subsection{Teknik Pengumpulan Data}

Metode yang dipakai dalam penelitian ini yaitu metode penelitian survei dengan beberapa tahapan. Jenis data yang dikumpulkan berupa data primer dan data sekunder. Data primer merupakan data yang diperoleh langsung dari lapangan melalui pengukuran dan pengamatan yang secara garis besar meliputi persentase tutupan karang, kelimpahan ikan karang dan parameter kualitas lingkungan perairan.

Data sekunder merupakan data yang diperoleh dari penelusuran terhadap laporan hasil penelitian atau kegiatan dilokasi yang sama dan data dari instansi terkait. Pengumpulan data sekunder dilakukan melalui studi kepustakaan seperti laporan hasil survei dan publikasi lainnya serta peta-peta yang tersedia.

\subsubsection{Persentase Tutupan Terumbu Karang}

Metode pengukuran tutupan terumbu karang yang digunakan adalah metode LIT (Line Intercept
Transect) mengikuti English et al. (1997) dalam Widikurina (2016), dengan beberapa modifikasi. Pengukuran tutupan karang dengan metode LIT didasarkan pada bentuk pertumbuhan terumbu karang. Penentuan bentuk pertumbuhan pada penelitian ini didasarkan pada data identifikasi bentuk pertumbuhan terumbu karang menurut versi AIMS (Australian Institute of Marine Science). Transek garis berupa roll meter dibentangkan sepanjang 50 meter sejajar dengan garis pantai. Panjang setiap bentuk pertumbuhan dan substrat yang bersinggungan dengan transek garis di sepanjang 50 meter dicatat menggunakan alat tulis bawah air. Pengambilan data panjang bentuk pertumbuhan terumbu karang dilakukan pada kedalaman 5 meter untuk kategori snorkeling dan 10 meter untuk kategori selam sebanyak satu kali pada setiap stasiun pengamatan.

\subsubsection{Jenis dan Jumlah Spesies Ikan Karang}

Jenis dan jumlah ikan karang yang ada di perairan Desa Tulamben dikaji menggunakan metode underwater visual census (UVC). Metode pengambilan data jenis dan jumlah ikan karang dilakukan sepanjang 50 meter pada kedalaman yang sama dengan pengambilan data tutupan terumbu karang. Jumlah dan jenis spesies ikan karang dicatat hingga batas 2,5 meter ke kiri dan 2,5 ke kanan dari transek garis. Pengamatan ikan karang ditunjang dengan buku identifikasi ikan karang berdasarkan Allen., et al dan Kuiter and Debelius.

\subsubsection{Parameter Kualitas Lingkungan Perairan}

Pengukuran arah dan kecepatan arus dilakukan dengan menggunakan layang-layang arus (drift float). Kecerahan diukur dengan menggunakan Secchidisk yang diikat dengan menggunakan tali berskala yang telah diketahui panjangnya, selanjutnya dimasukkan ke dalam perairan secara perlahan-lahan hingga tidak tampak secara visual. Nilai kecerahan dihitung dengan mempresentasekan panjang tali saat Secchidisk masih terlihat dan tidak terlihat lagi sama sekali.

Kedalaman terumbu karang diukur menggunakan Dive computer, untuk pengukuran suhu dapat dilihat pada Dive computer yang juga dapat membaca nilai suhu saat mengukur kedalaman pada titik pengamatan. 


\subsection{Analisa Data}

\subsubsection{Persentase Penutupan Karang}

Data persen penutupan karang hidup yang diperoleh berdasarkan metode Line Intersept Transect (LIT) dihitung berdasarkan persamaan dari English et al. (1997) dalam Widikurina (2016) :

$L=\frac{L i}{N} \times 100 \%$

dimana $L$ adalah persentase penutupan karang (\%); $L i$ adalah panjang bentuk pertumbuhan jenis kategori ke-i (m); dan $N$ adalah panjang transek (m)

Kategori kondisi dalam persentase penutupan karang hidup berdasarkan Gomez dan Yap dalam Widikurnia (2016) menyatakan kriteria baku mutu untuk kondisi terumbu karang (Tabel 2).

Tabel 2

Kategori tutupan karang berdasarkan Gomez dan Yap (1988)

\begin{tabular}{cc}
\hline Persentase Penutupan & Kriteria Penilaian \\
\hline $0-24,9$ & Rusak \\
$25-49,9$ & Sedang \\
$50-74,9$ & Baik \\
$75-100$ & Sangat Baik \\
\hline
\end{tabular}

\subsubsection{Kecerahan Perairan}

Kecerahan perairan diukur dengan menggunakan secchidisk dan dinyatakan dalam persen. Rumus yang digunakan untuk menghitung kecerahan perairan pada stasiun pengamatan adalah sebagai berikut :

$$
N=\frac{D_{1}+D_{2}}{2}
$$

$D_{1}$ menunjukkan kedalaman pada saat secchidisk tidak tampak (cm); $D_{2}$ merupakan kedalaman pada saat secchidisk mulai tampak (cm); dan $N$ adalah kecerahan perairan $(\mathrm{cm})$. Rumus yang digunakan untuk mengetahui persentase kecerahan perairan pada stasiun pengamatan :

$$
X=\frac{N}{D} \times 100 \%
$$

$\mathrm{X}$ merupakan kecerahan perairan dalam persen (\%); $N$ adalah kecerahan perairan $(\mathrm{cm}) ;$ dan Dadalah kedalaman terumbu karang pada stasiun pengamatan $(\mathrm{cm})$.

\subsubsection{Indeks Kesesuaian Wisata Kategori Snorkeling}

Kategori wisata snorkeling mempertimbangkan tujuh parameter dengan tiga klasifikasi penilaian (Tabel 3). Parameter kesesuaian wisata snorkeling antara lain kecerahan perairan, tutupan komunitas karang, jenis bentuk pertumbuhan, jenis ikan karang, kecepatan arus, kedalaman terumbu karang dan lebar hamparan datar karang (Yulianda, 2007 dalam Widikurnia, 2016 ). Dalam penelitian ini parameter kesesuaian wisata snorkeling dimodifikasi sesuai dengan kondisi di perairan Tulamben. Bobot dan skor parameter lebar hamparan datar karang diabaikan dikarenakan dari semua stasiun yang ada tidak memenuhi syarat untuk parameter ini.

Tabel 3

Matriks kesesuaian wisata bahari kategori snorkeling

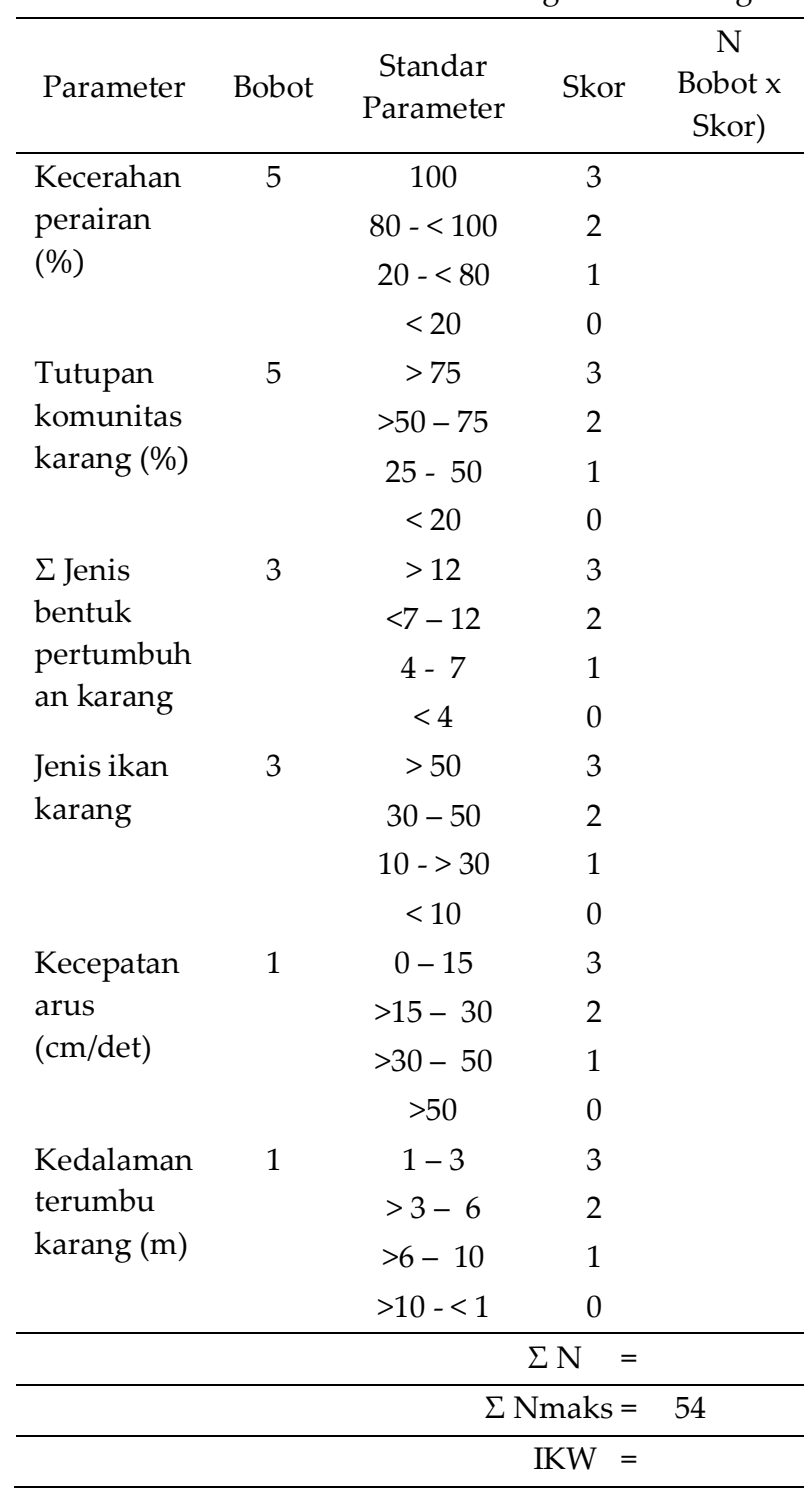

Sumber : Yulianda, 2007 dalam Widikurnia, 2016 (modifikasi) 
Selanjutnya untuk menentukan indeks kesesuaian pemanfaatan untuk wisata snorkeling menggunakan formula:

$$
I K W=\sum_{i=1}^{n}\left[\frac{N i}{N \max }\right] \times 100 \%
$$

dimana $I K W$ adalah indeks kesesuaian wisata snorkeling; $N_{i}$ adalah nilai parameter ke-i (bobot $\mathrm{x}$ skor); dan $N_{\max }$ adalah nilai maksimum dari suatu kategori wisata $=54$

Kategori kelas kesesuaian untuk kegiatan wisata snorkeling berdasarkan Yulianda (2007) dalam Widikurnia (2016) menyatakan kategori tingkat kesesuaian berdasarkan nilai IKW (Tabel 4). Tingkat kesesuaian tersebut dibagi menjadi tiga, yaitu kategori sangat sesuai (S1), sesuai (S2) dan tidak sesuai $(\mathrm{N})$.

Tabel 4

Kategori kelas kesesuaian berdasarkan Yulianda (2007)

\begin{tabular}{ccc}
\hline Nilai IKW $(\%)$ & Kategori & Keterangan \\
\hline $83-100$ & S1 & Sangat sesuai \\
$50-<83$ & S2 & Sesuai \\
$<50$ & N & Tidak sesuai \\
\hline
\end{tabular}

Sumber : Yulianda (2007) dalam Widikurnia (2016)

\subsubsection{Indeks Kesesuaian Wisata Kategori Selam}

Parameter kesesuaian wisata bahari kategori wisata selam antara lain kecerahan perairan, tutupan komunitas karang, jenis bentuk pertumbuhan, jenis ikan karang, kecepatan arus, dan kedalaman terumbu karang (Tabel 5).

Nilai yang didapatkan dari setiap parameter kesesuaian ekowisata selam di perairan Tulamben kemudian dikalkulasi menggunakan rumus Indeks Kesesuaian Wisata. Pengkajian mengenai indeks kesesuaian pemanfaatan wisata selam menurut Yulianda (2007) dalam Widikurnia (2016) di formulasikan sebagai berikut:

$$
I K W=\sum_{i=1}^{n}\left[\frac{N i}{N \max }\right] \times 100 \%
$$

dimana $I K W$ adalah indeks kesesuaian wisata (\%); $N_{i}$ adalah nilai parameter ke-i (Bobot x skor); dan $N_{\text {maks }}$ adalah nilai maksimum (selam $\left.=54\right)$.

Ketentuan kelas kesesuaian untuk kegiatan wisata selam berdasarkan Yulianda (2007) dalam Widikurnia (2016) dikategorikan menjadi sangat sesuai (S1), dengan IKW 83 - 100 \%; sesuai (S2), dengan IKW 50 - < $83 \%$; dan tidak sesuai (N), dengan IKW $<50 \%$.

Tabel 5

\begin{tabular}{|c|c|c|c|c|}
\hline Parameter & Bobot & $\begin{array}{c}\text { Standar } \\
\text { Parameter }\end{array}$ & Skor & \begin{tabular}{l}
\multicolumn{1}{c}{$\mathrm{N}$} \\
Bobot $x$ \\
Skor)
\end{tabular} \\
\hline $\begin{array}{l}\text { Kecerahan } \\
\text { perairan } \\
(\%)\end{array}$ & 5 & $\begin{array}{c}80 \\
50-80 \\
20-<50 \\
<20\end{array}$ & $\begin{array}{l}3 \\
2 \\
1 \\
0\end{array}$ & \\
\hline $\begin{array}{l}\text { Tutupan } \\
\text { komunitas } \\
\text { karang (\%) }\end{array}$ & 5 & $\begin{array}{c}>75 \\
>50-75 \\
25-50 \\
<25\end{array}$ & $\begin{array}{l}3 \\
2 \\
1 \\
0\end{array}$ & \\
\hline $\begin{array}{l}\Sigma \quad \text { Jenis } \\
\text { bentuk } \\
\text { pertumbuh } \\
\text { an karang }\end{array}$ & 3 & $\begin{array}{c}>12 \\
<7-12 \\
4-7 \\
<4 \\
>100\end{array}$ & $\begin{array}{l}3 \\
2 \\
1 \\
0 \\
3\end{array}$ & \\
\hline $\begin{array}{l}\text { Jenis ikan } \\
\text { karang }\end{array}$ & 3 & $\begin{array}{c}50-100 \\
20-<50 \\
\quad<20\end{array}$ & $\begin{array}{l}2 \\
1 \\
0\end{array}$ & \\
\hline $\begin{array}{l}\text { Kecepatan } \\
\text { arus } \\
(\mathrm{cm} / \text { det})\end{array}$ & 1 & $\begin{array}{c}0-15 \\
>15-30 \\
>30-50 \\
>50\end{array}$ & $\begin{array}{l}3 \\
2 \\
1 \\
0\end{array}$ & \\
\hline $\begin{array}{l}\text { Kedalaman } \\
\text { terumbu } \\
\text { karang } \\
\text { (m) }\end{array}$ & 1 & $\begin{array}{c}6-15 \\
3-<6 \&>15- \\
20 \\
>20-30 \\
<3 \&>30\end{array}$ & $\begin{array}{l}3 \\
2 \\
1 \\
0\end{array}$ & \\
\hline & & \multicolumn{3}{|c|}{$\Sigma \mathrm{N}$} \\
\hline & & \multicolumn{2}{|c|}{$\Sigma$ Nmaks $=$} & 54 \\
\hline
\end{tabular}

Matriks kesesuaian wisata bahari kategori selam

Sumber : Yulianda (2007) dalam Widikurnia (2016)

\section{Hasil dan Pembahasan}

\subsection{Kondisi Parameter Lingkungan di Perairan} Tulamben

Yulianda (2007) dalam Andry (2003), merumuskan beberapa parameter yang dapat mempengaruhi kelayakan suatu perairan untuk dijadikan lokasi wisata selam dan snorkeling. Parameter tersebut termasuk kondisi ekosistem terumbu karang dan juga kondisi oseanografi perairan. Ekosistem terumbu karang yang perlu diperhatikan yaitu, tutupan komunitas karang, banyaknya jenis bentuk pertumbuhan karang, banyaknya jenis ikan. Sedangkan untuk oseanografi yang diperhatikan yaitu, kedalaman perairan, kecepatan arus dan kecerahan perairan. 


\subsubsection{Tutupan Karang Hidup}

Persentase tutupan karang hidup pada stasiun pengamatan di perairan Tulamben berkisar antara $16,26 \%$ sampai dengan $52,48 \%$. Persentase tutupan karang hidup tebesar terdapat di Coral Garden pada kedalaman 5 meter (stasiun 3) dengan persentase sebesar $52,48 \%$ sedangkan persentase tutupan karang hidup terkecil terdapat di Shipwreck kedalaman 5 meter (stasiun 1) yakni 16,26\%. Pada daerah Shipwreck kedalaman 10 meter (stasiun 2) presentase tutupan karang sebesar 29,58\%, daerah coral garden kedalaman 10 meter (stasiun 4) sebesar $42,24 \%$, sementara daerah Drop Off kedalaman 5 dan 10 meter (Stasiun 5 dan 6) masing-masing sebesar 25,64 dan $37,96 \%$ (Gambar 4).

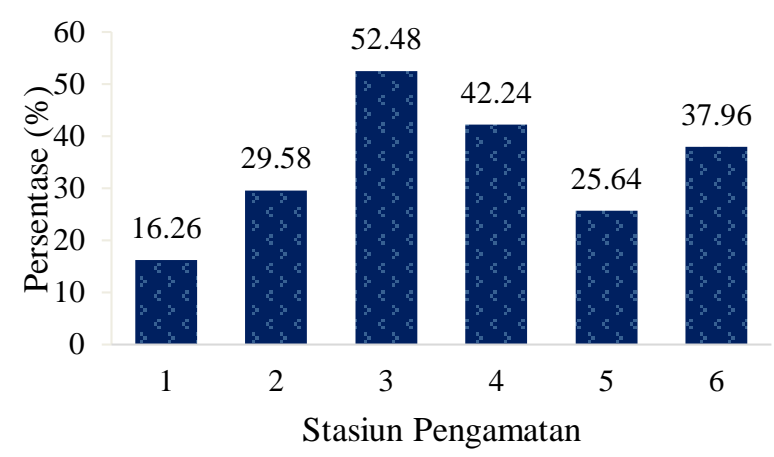

Gambar 4. Persentase tutupan karang hidup di setiap stasiun pengamatan

Berdasarkan kriteria baku mutu terumbu karang oleh Gomez and Yap, kondisi terumbu karang berdasarkan hasil tutupan karang hidup yang diperoleh di perairan Tulamben termasuk dalam kriteria rusak hingga baik. Terumbu karang dengan kondisi rusak terdapat di stasiun 1 sedangkan terumbu karang dalam kondisi baik terdapat di stasiun 3. Pada stasiun 2, 4, 5, dan 6, kondisi terumbu karang termasuk dalam kriteria sedang. Hasil penelitian ini menunjukkan bahwa terjadi penurunan persentase dan kondisi tutupan karang di perairan Tulamben. Menurut hasil penelitian dari Trialfhianty (2013), kondisi terumbu karang di perairan pantai perairan laut Tulamben termasuk dalam kategori sedang hingga baik dengan tutupan karang hidup sebesar 38,3\%$53 \%$. Persentase tutupan karang hidup terkecil mengalami penurunan sebesar $22,04 \%$ atau dalam kriteria sedang turun menjadi kriteria rusak. Sementara tutupan karang hidup terbesar mengalami penurunan sebesar $0,52 \%$ namun tetap dalam kriteria baik.
Berdasarkan standar parameter matriks kesesuaian wisata bahari kategori wisata snorkeling menurut Yulianda (2007) dalam Yusniar (2010), parameter tutupan komunitas karang pada daerah Shipwreck (stasiun 1) mendapatkan skor nol, daerah Coral Garden (stasiun 3) mendapatkan skor 2, dan daerah Drop Off (stasiun 5) mendapatkan skor 1. Sementara standar parameter matriks kesesuaian wisata bahari kategori wisata selam, tutupan komunitas karang pada daerah Shipwreck (stasiun 2), Coral Garden (stasiun 4), dan Drop Off (stasiun 6) masing-masing mendapatkan skor 1 .

\subsubsection{Jenis Bentuk Pertumbuhan Terumbu Karang}

Keanekaragaman jenis bentuk pertumbuhan menjadi salah satu parameter dan daya tarik dalam pengembangan wisata selam dan snorkeling. Semakin beragam bentuk pertumbuhan terumbu karang, semakin beragam atraksi yang dapat dilihat oleh penyelam. Hal tersebut berdampak baik bagi pengembangan kawasan wisata selam dan snorkeling di perairan Tulamben. Persentase jumlah tutupan karang keras hidup di suatu lokasi dapat mempengaruhi minat penyelam untuk melakukan kegiatan wisata selam (Williams and Polunin 2000 dalam Widikurnia 2016).

Karang memiliki variasi bentuk pertumbuhan koloni yang berkaitan dengan kondisi lingkungan perairan. Berbagai jenis bentuk pertumbuhan karang dipengaruhi oleh intensitas cahaya matahari, hidrodinamis (arus dan gelombang), ketersediaan bahan makanan, sedimen, subareal exposure dan faktor genetik (Suharsono, 2000 dalam Suryanti, 2011). Ekosistem terumbu karang di stasiun pengamatan perairan Tulamben memiliki 18 bentuk pertumbuhan.

Karakteristik pantai pada daerah Shipwreck kedalaman 5 meter (stasiun 1) tersusun dari batuan vulkanik hingga kedalaman 5 meter dan lebih dalam lagi berupa hamparan pasir. Pada stasiun 1 ditemukan sebanyak 6 bentuk pertumbuhan. Pertumbuhan karang non-Acropora diwakili oleh pertumbuhan submasif dan bentuk kerak (encrusting) sebesar 16,26\%). Bentuk pertumbuhan submasif berupa tonjolan-tonjolan kokoh atau kolom-kolom kecil, sementara bentuk pertumbuhan kerak (encrusting) tumbuh menyerupai dasar terumbu dengan permukaan yang kasar dan keras serta berlubang-lubang kecil. Bentuk pertumbuhan ini banyak terdapat pada 
lokasi yang terbuka dan berbatu-batu, terutama mendominasi sepanjang lereng tepi terumbu dan bersifat memberikan tempat berlindung untuk hewan-hewan kecil yang sebagian tubuhnya tertutup cangkang (Supriharyono, 2000 dalam Suryanti, 2011).

Bentuk pertumbuhan karang pada stasiun 1 juga dipengaruhi oleh gelombang, dimana stasiun 1 adalah daerah yang memiliki gelombang yang relatif kuat. Menurut Supriharyono (2000) dalam Suryanti (2011), gelombang berpengaruh terhadap perubahan bentuk koloni terumbu. Karang yang hidup pada daerah yang memiliki gelombang yang kuat (windward zones) kecenderungan pertumbuhan berbentuk percabangan pendek, kuat, merayap atau submasif.

Komponen abiotik pada stasiun 1 memiliki persentase tutupan yang paling tinggi yaitu sebesar $43,68 \%$ dan $22,1 \%$ nya berupa batu (RCK). Sementara komponen biota lainnya ditemukan sebesar 40,06\%. Biota lainnya yang ditemukan yaitu turf alga (TA) (Gambar 5).

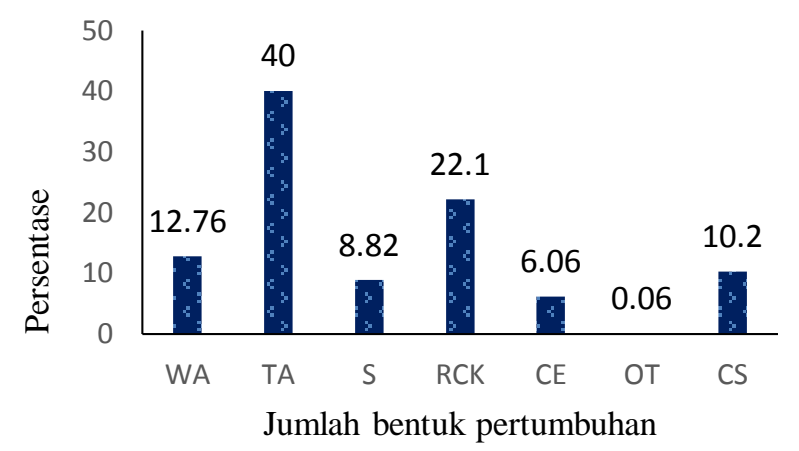

Gambar 5. Persentase tutupan setiap bentuk pertumbuhan karang di stasiun 1

Banyaknya persentase turf alga (TA) yang ditemukan diduga menjadi penyebab terumbu karang tidak dapat hidup dengan baik di stasiun 1 . Menurut Adrim et al., (2012), dalam ekosistem terumbu karang, alga mempunyai peranan yang penting yaitu : produsen primer karena dapat berfotosintesis dan merupakan makanan bagi ikan herbivora, membantu konstruksi dan cementasi terumbu karang dengan menghasilkan calcium carbonate namun jika jumlahnya semakin banyak maka berdampak negatif bagi terumbu karang. Alga memiliki kemampuan tumbuh lebih cepat sehingga dapat menutupi areal terumbu karang. kondisi ini dapat menyebabkan perubahan struktur komunitas dari komunitas terumbu karang ke komunitas alga, menyebabkan degradasi terumbu karang namun tergantung pada jenis alga.

Pada stasiun 2, substrat dasar perairan berupa hamparan pasir. Terdapat bangkai kapal USAT Liberty yang banyak ditumbuhi terumbu karang dan menjadi obyek wisata utama penyelaman di Tulamben. Menurut Nontji (2005) dalam Salsabiela (2014), kapal yang tenggelam di dasar laut dapat ditumbuhi berbagai jenis hewan karang. Berdasarkan hasil LIT, ditemukan sebanyak 11 bentuk pertumbuhan karang pada stasiun 2 . Persentase tutupan karang hidup sebesar 29,58\% yang terdiri dari pertumbuhan karang Acropora (Acropora Digitate dan Acropora Encrusting) dan pertumbuhan karang non-Acropora (Coral Encrusting, Coral Foliose, Coral Masive). Menurut Suharsono (2000) dalam Suryanti (2011), bentuk lembaran (foliose) merupakan lembaran-lembaran yang menonjol pada dasar terumbu, membentuk lipatan atau melingkar, bentuk pertumbuhan ini ditemukan di daerah-daerah yang terlindung. Pada penelitian ini, bentuk lembaran ditemukan di celah atau di dekat bangkai kapal. Komponen abiotik mempunyai persentase yang tinggi dan mendominasi pada stasiun ini yaitu sebesar $50,48 \%$, sedangkan komponen biotik dan biota lainnya masing-masing ditemukan sebesar 8,16\% dan 11,78\% (Gambar 6).

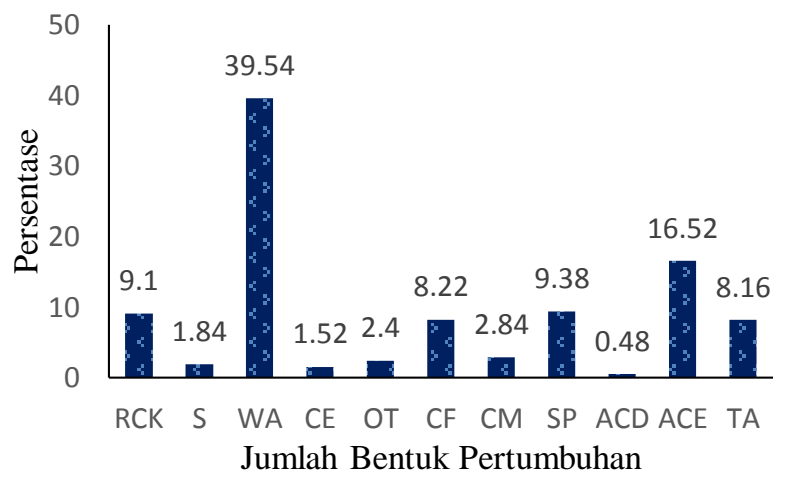

Gambar 6. Persentase tutupan setiap bentuk pertumbuhan karang di stasiun 2

Daerah Coral Garden secara umum berupa hamparan pasir, dibeberapa titik dapat ditemukan substrat-substrat yang ditumbuhi karang sehingga bisa dikatakan penyebaran terumbu karang di daerah ini tidak merata. Jumlah bentuk pertumbuhan yang ditemukan pada stasiun 3 sebanyak 14 bentuk pertumbuhan. Persentase tutupan karang sebesar $52,48 \%$ terdiri dari bentuk pertumbuhan Acropora (Acropora Digitate, Acropora branching, Acropora Submasive, Acropora Tabulate) 
dan non-Acropora (Coral Masive, Coral Mushroom, Coral Foliose, Coral Encrusting). Komponen biotik dan biota lainnya masing-masing sebesar 6,06\% dan $15,84 \%$, sementara komponen abiotik sebesar $25,62 \%$. Sebesar $14,48 \%$ dari komponen abiotik berupa pasir (S) (Gambar 7).

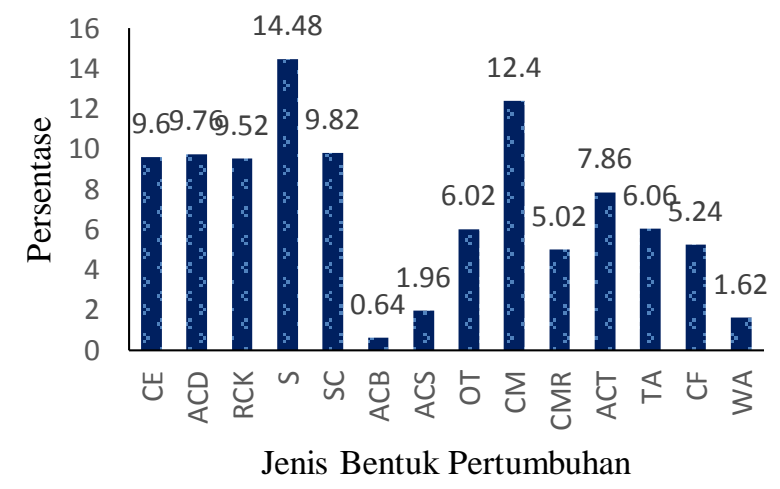

Gambar 7. Persentase tutupan setiap bentuk pertumbuhan karang di stasiun 3

Daerah Coral Garden pada kedalaman 10 meter (stasiun 4), berdasarkan hasil LIT ditemukan sebanyak 15 bentuk pertumbuhan karang. Persentase tutupan karang pada stasiun ini sebesar 42,24\% terdiri dari bentuk pertumbuhan Acropora (Acropora Digitate, Acropora Tabulate, Acropora Branching) dan non-Acropora (Coral Masive, Coral Encrusting, Coral Foliose, Coral Mushroom. Komponen abiotik sebesar 50,5\%, 22,56\% diantaranya berupa pasir, sementara komponen biotik dan biota lainnya masing-masing sebesar 2,38\% dan 4,18\% (Gambar 8). Sama dengan stasiun 3, pada stasiun ini persentase tutupan pasir tergolong tinggi. Pada stasiun 4 juga ditemukan terumbu karang buatan.

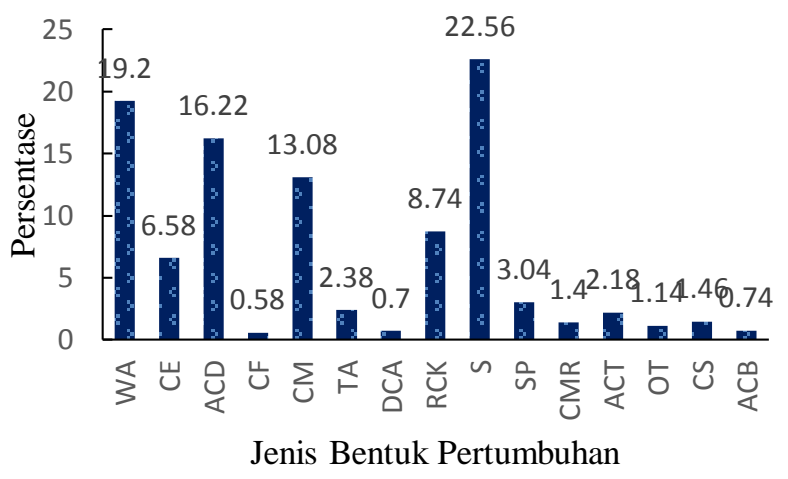

Gambar 8. Persentase tutupan setiap bentuk pertumbuhan karang di stasiun 4

Situs penyelaman ini juga biasa disebut dengan Tulamben Wall karena bentuknya berupa dinding atau jurang terjal yang ditumbuhi karang. Berdasarkan hasil LIT, pada stasiun ini didominasi oleh air (WA) yaitu sebesar 56,86\% dari total komponen abiotik sebesar 68,22\%. Persentase tutupan karang pada stasiun 5 tercatat sebesar 25,64\% terdiri dari bentuk pertumbuhan Acropora (Acropora Digitate, Acropora Submasive, Acropora Encrusting) dan non-Acropora (Coral Masive, Coral Foliose, Coral Encrusting, Coral Submasive. Sementara persentase komponen biotik dan biota lainnya masing-masing sebesar $0,58 \%$ dan 5,56\% (Gambar 9).

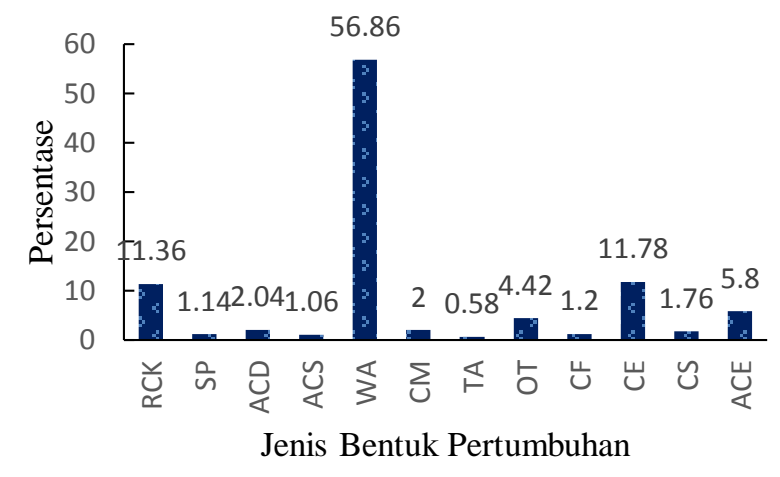

Gambar 9. Persentase tutupan setiap bentuk pertumbuhan karang di stasiun 5

Sama seperti stasiun 5, terumbu karang di stasiun ini tumbuh menempel di dinding secara vertikal hingga kedalaman mencapai 60-70 meter. Kondisi ini mengakibatkan tutupan terumbu karang didominasi oleh komponen abiotik sebesar $46,76 \%$ dengan 41,22\% diantaranya berupa air (WA). Persentase tutupan karang tercatat sebesar 37,96\% terdiri dari bentuk pertumbuhan Acropora (Acropora Tabulate, Acropora Digitate) dan nonAcropora (Coral Submasive, Coral Encrusting, Coral Masive, Coral Foliose), sementara komponen biotik sebesar $1,58 \%$ dan biota lainnya tercatat sebesar $13,7 \%$ (Gambar 10).

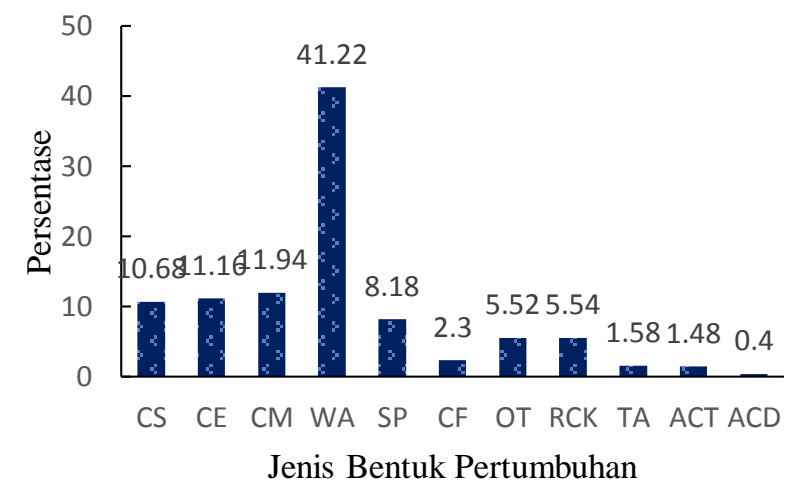

Gambar 10. Persentase tutupan setiap bentuk pertumbuhan karang di stasiun 6 


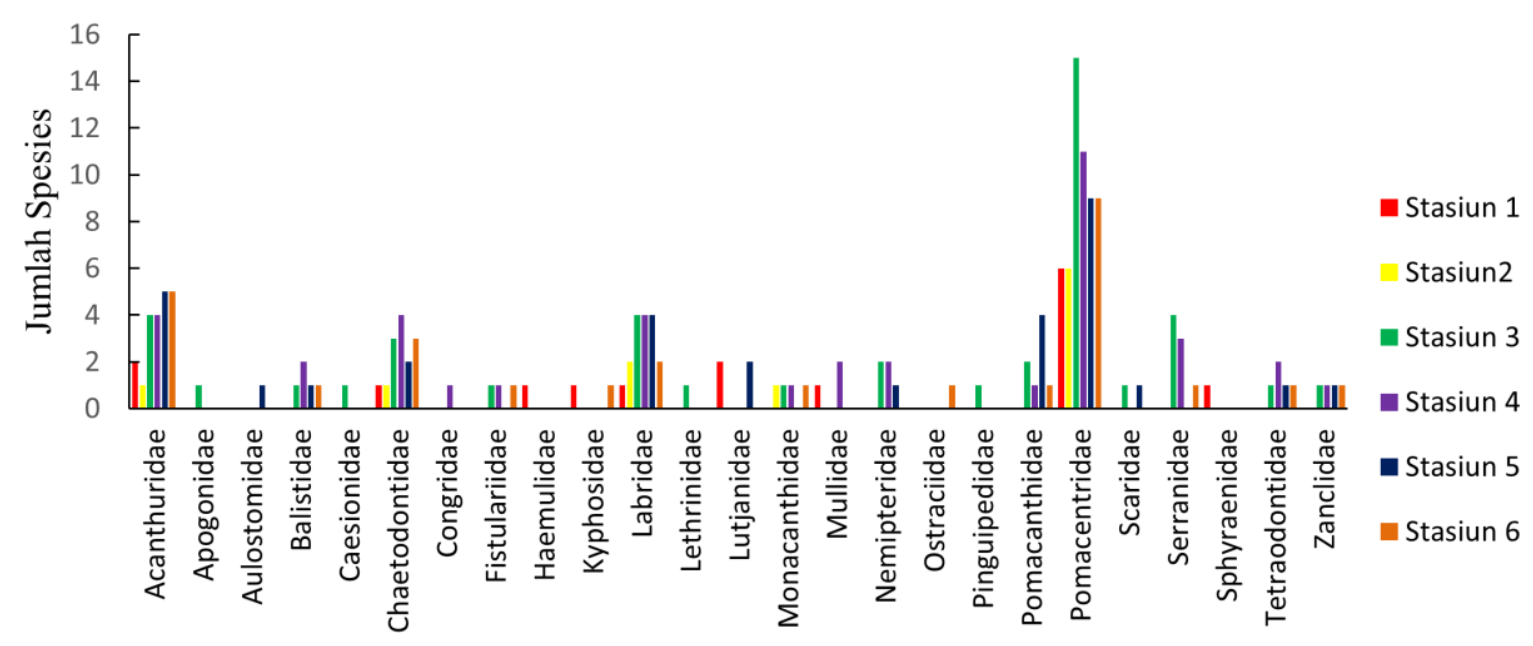

Famili

Gambar 11. Jumlah jenis spesies ikan karang pada setiap famili

Menurut Richmond (1987) dalam Bato (2013), substrat dasar perairan merupakan faktor pembatas yang sangat penting bagi karang, karena dalam fase hidup karang hanya bebas bergerak dalam jumlah waktu terbatas terutama pada saat larva planula. Fase berikutnya memerlukan substrat untuk tempat menempel dan melekat secara permanen untuk selama hidupnya.

\subsubsection{Jenis Ikan Karang}

Selain terumbu karang, keberadaan ikan karang juga menjadi daya tarik dalam pengembangan kegiatan wisata selam dan snorkeling. Semakin banyak jenis ikan karang yang ditemukan maka semakin baik untuk pengembangan kegiatan wisata (Yulianda, 2007 dalam Widikurnia, 2016).

Berdasarkan hasil penelitian tedapat 100 spesies dalam 25 famili ikan karang yang ditemukan pada enam titik stasiun pengamatan. Jumlah spesies terbanyak terdapat di stasiun 3 yaitu sebanyak 44 spesies dan paling sedikit ditemukan pada stasiun 1 sebanyak 16 spesies. Chromis margaritifer merupakan spesies dari famili Pomacentridae dengan jumlah individu terbanyak dan ditemukan di seluruh stasiun pengamatan (Gambar 11).

Persentase famili ikan karang yang didapatkan pada stasiun pengamatan di perairan Tulamben menggambarkan perbandingan jumlah individu spesies pada setiap famili ikan karang. Famili ikan karang Pomacentridae merupakan famili ikan karang yang memiliki persentase terbesar pada stasiun pengamatan yakni sebesar $75 \%$ dari kelimpahan total ikan karang yang ditemukan (Gambar 12). Hal ini menunjukkan bahwa famili Pomacentridae merupakan kelompok ikan yang dapat berasosiasi kuat dengan terumbu karang dengan menjadikan terumbu karang sebagai habitat dan tempat mencari makan. Selain itu kelompok ikan ini dapat mengikis lendir pada koloni karang Selarectinia (Haruddin et al., 2011). Famili Pomacentridae merupakan ikan karang yang paling banyak jenisnya dan sebagian besar memang berasosiasi dengan terumbu karang. Dominasi spesies dari famili Pomacentridae ini disebabkan juga oleh sifat mereka yang teritorialisme, dimana ikan ini relatif stabil dan dijumpai mulai dari daerah pasang surut sampai kedalaman 40 meter (Montgomery et al., 1980 dalam Widikurnia, 2016). Keberadaan famili ini juga sangat dipengaruhi oleh substrat, bahkan beberapa spesies diantaranya cenderung menggunakan karang sebagai habitat untuk mencari makan (Dahiyat et al., 2003).

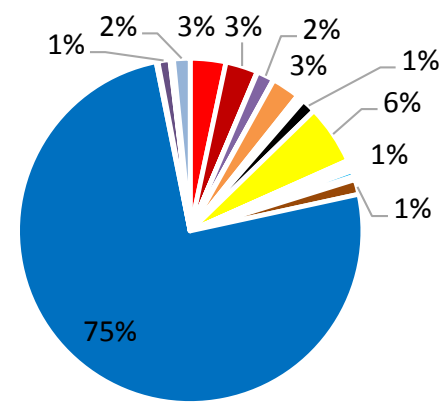

- Acanthuridae

- Apogonidae

- Balistidae

- Chaetodontidae

Labridae

- Lutjanidae

- Nemipteridae

- Pomacanthidae

- Pomacentridae

- Zanclidae

Gambar 12. Persentase perbandingan jumlah individu spesies pada setiap famili ikan karang 
Di perairan Tulamben ditemukan juga famili Chaetodontidae. Jumlah spesies dari famili Chaetodontidae ditemukan sebanyak 3\% dari jumlah total spesies ikan yang ditemukan. Adrim et al., (2012) menyatakan bahwa kelompok ikan Chaetodontidae memiliki asosiasi yang sangat kuat dengan ekosistem terumbu karang dan dapat digunakan sebagai ikan indikator kesehatan karang. Bouchon-Navaro et al (1985) dalam Suryanti (2011) menambahkan bahwa ikan Chaetodontidae sangat sensitif terhadap perubahan dan kerusakan karang, karena ikanikan ini sangat terikat terhadap makanan dan tempat berlindung yang disediakan oleh karang. Namun keberadaan famili Chaetodontidae dan indikasinya terhadap kondisi kesehatan terumbu karang di beberapa lokasi di perairan Tulamben diperlukan penelitian lebih lanjut.

Pada stasiun 1 ditemukan sebanyak 198 individu ikan karang yang tergolong dalam 16 spesies. Spesies-spesies tersebut tergolong dalam 9 famili yaitu, Acanthuridae, Chaetodontidae, Haemulidae, Kyphosidae, Labridae, Lutjanidae, Mullidae, Pomacentridae dan Sphyraenidae (Gambar 13). Spesies dengan jumlah individu terbanyak yaitu Chromis margaritifer yang merupakan famili Pomacentridae. Berdasarkan matriks kesesuaian wisata kategori wisata snorkeling, jumlah ikan karang pada stasiun 1 mendapatkan skor 1.

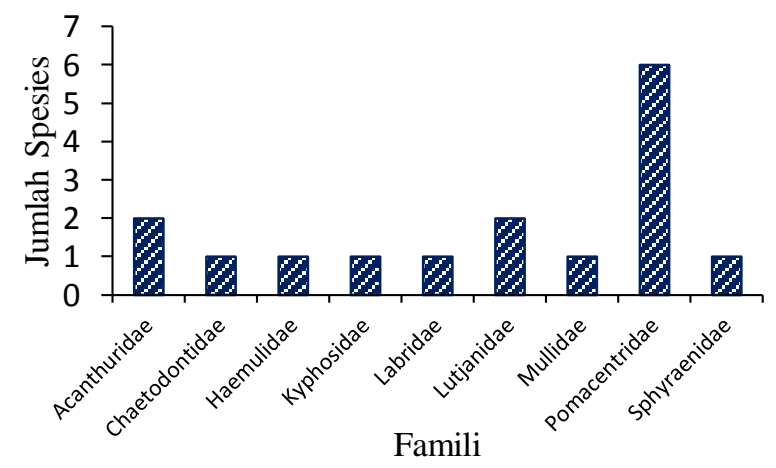

Gambar 13. Jumlah jenis spesies ikan karang pada setiap famili di stasiun 1

Berdasarkan hasil penelitian dengan metode underwater visual census (UVS), pada stasiun 2 diperoleh sebanyak 5 famili ikan karang yang terdiri dari 11 spesies dan 67 individu. Famili ikan karang yang dijumpai yaitu famili Pomacentridae, Labridae, Chaetodontidae, Acanthuridae dan Monacanthidae. Spesies Chromis margaritifer yang termasuk dalam famili Pomacentridae menjadi spesies yang paling banyak ditemukan pada stasiun ini (Gambar 14). Berdasarkan matriks kesesuaian wisata kategori wisata selam, jumlah ikan karang pada stasiun 2 mendapatkan skor nol.

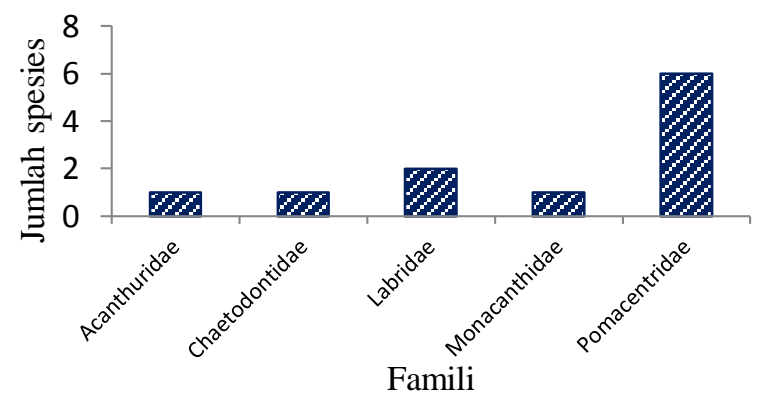

Gambar 14. Jumlah jenis spesies ikan karang pada setiap famili di stasiun 2

Hasil penelitian pada stasiun 3 ditemukan sebanyak 17 famili yaitu famili Acanthuridae, Apogonidae, Balistidae, Caesionidae, Chaetodontidae, Fistulariidae, Labridae, Lethrinidae, Monacanthidae, Nemipteridae, Pinguipedidae, Pomacanthidae, Pomacentridae, Scaridae, Serranidae, Tetraodontidae dan Zanclidae. Spesies yang ditemukan sebanyak 44 spesies dan 599 individu. Individu terbanyak yang ditemukan yaitu Chromis margaritifer yang berasal dari famili Pomacentridae (Gambar 15). Berdasarkan matriks kesesuaian wisata kategori wisata snorkeling, jumlah ikan karang pada stasiun 3 mendapatkan skor 2.

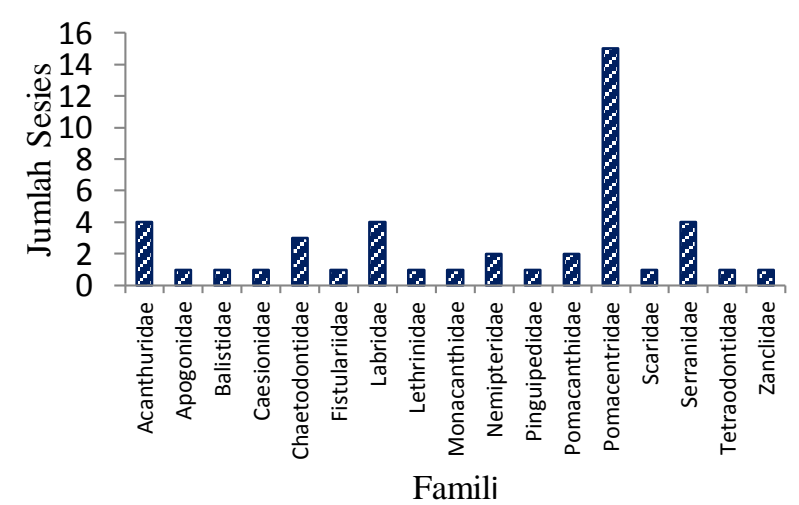

Gambar 15. Jumlah jenis spesies ikan karang pada setiap famili di stasiun 3

Pada stasiun 4 diperoleh 14 famili ikan karang yaitu famili Acanthuridae, Balistidae, Chaetodontidae, Congridae, Fistulariidae, Labridae, Monacanthidae, Mullidae, Nemipteridae, Pomacanthidae, Pomacentridae, Serranidae, Tetraodontidae dan Zanclidae. Spesies yang ditemukan sebanyak 39 spesies dan 527 individu. 
Spesies yang paling banyak ditemukan yaitu Chrysiptera coeruleolineata dari famili Pomacentridae (Gambar 16). Berdasarkan matriks kesesuaian wisata kategori wisata selam, jumlah ikan karang pada stasiun 4 mendapatkan skor 1 .

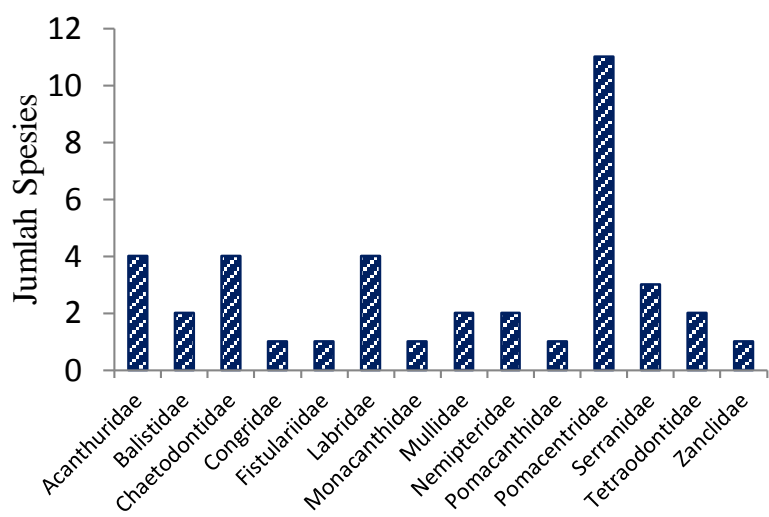

Famili

Gambar 16. Jumlah jenis spesies ikan karang pada setiap famili di stasiun 4

Pada stasiun 5 diperoleh 12 famili ikan karang yaitu famili Acanthuridae, Aulostomidae, Balistidae, Chaetodontidae, Labridae, Lutjanidae, Nemipteridae, Pomacanthidae, Pomacentridae, Scaridae, Tetraodontidae dan Zanclidae. Spesies yang ditemukan sebanyak 32 spesies dan 211 individu. Spesies yang paling banyak ditemukan yaitu Chromis margaritifer dari famili Pomacentridae (Gambar 17). Berdasarkan matriks kesesuaian wisata kategori wisata snorkeling, jumlah ikan karang pada stasiun 5 mendapatkan skor 2.

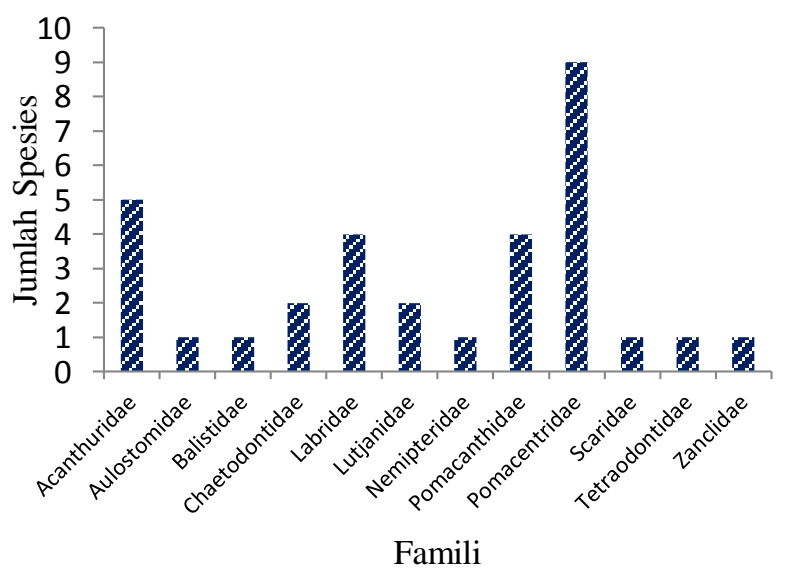

Gambar 17. Jumlah jenis spesies ikan karang pada setiap famili di stasiun 5
Pada stasiun 6 diperoleh 13 famili ikan karang yaitu famili Acanthuridae, Balistidae, Chaetodontidae, Fistulariidae, Kyphosidae, Labridae, Monacanthidae, Ostraciidae, Pomacanthidae, Pomacentridae, Serranidae, Tetraodontidae dan Zanclidae. Spesies yang ditemukan sebanyak 28 spesies dan 260 individu. Spesies yang paling banyak ditemukan yaitu Abudefduf sexfasciatus dari famili Pomacentridae (Gambar 18). Berdasarkan matriks kesesuaian wisata kategori wisata selam, jumlah ikan karang pada stasiun 6 mendapatkan skor 1 .

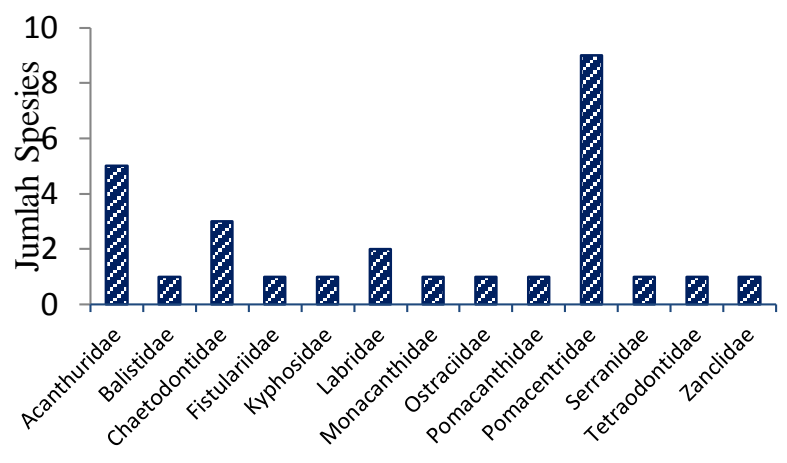

Famili

Gambar 18. Jumlah jenis spesies ikan karang pada setiap famili di stasiun 6

\subsubsection{Kedalaman Perairan}

Salah satu kegiatan penyelaman dan snorkeling dilakukan untuk menikmati keindahan di bawah laut, berupa ekosistem terumbu karang. Namun pemandangan ini dibatasi oleh kedalaman, seperti pada wisata snorkeling, sekalipun menggunakan masker kita tetap memiliki batas penglihatan di bawah laut. Untuk kegiatan penyelaman dibatasi oleh kedalaman terumbu karang, selain karena meningkatnya tekanan atmosfer berbanding lurus dengan bertambahnya kedalaman sehingga akan sangat beresiko pada kegiatan penyelaman, karang dibatasi oleh penetrasi cahaya yang diterimanya sehingga pada kedalaman tertentu tidak lagi ditemukan terumbu karang (Yulianda, 2007 dalam Andry, 2013).

Pengambilan data untuk kategori wisata snorkeling pada penelitian ini dilakukan pada kedalaman 5 meter, sedangkan untuk kategori wisata selam dilakukan pengambilan data pada kedalaman 10 meter. Skor yang diperoleh untuk kategori snorkeling adalah 2, sedangkan untuk kategori selam diperoleh skor 3 . 


\subsubsection{Kecepatan Arus}

Kecepatan arus merupakan faktor fisik yang berpengaruh langsung pada bentuk pertumbuhan karang. Arus yang kuat yang mengalir secara teratur akan mampu merubah bentuk pertumbuhan karang lebih kearah bentuk pertumbuhan mengerak (encrusting) (Supriharyono, 2000). Selain itu, kecepatan arus juga berkaitan dengan kenyamanan dan keamanan wisatawan dalam melakukan kegiatan snorkeling maupun selam (Yulianda, 2007 dalam Andry, 2013).

Pada pengamatan yang dilakukan, kecepatan arus berkisar antara 13-15 cm/det . Kecepatan arus tersebut tergolong lambat dan sangat kecil pengaruhnya terhadap perubahan bentuk pertumbuhan karang. Pada stasiun 1, 3, dan 4 kecepatan arus diperoleh sebesar $13 \mathrm{~cm} /$ det, stasiun 2 dan 6 sebesar $14 \mathrm{~cm} /$ det, dan stasiun 5 kecepatan arus diperoleh sebesar $15 \mathrm{~cm} /$ det. Skor yang diperol di seluruh stasiun adalah 3 .

\subsubsection{Kecerahan Perairan}

Kecerahan perairan merupakan hal yang penting dalam melakukan kegiatan snorkeling dan penyelaman, hal ini menyangkut visibility atau jarak pandang. Semakin baik jarak pandang maka keindahan bawah air juga akan semakin nyaman untuk dinikmati dengan mata dan kamera underwater (pemotretan dan video bawah laut) (Yulianda, 2007 dalam Andry, 2013). Kecerahan perairan juga merupakan faktor penting selain kondisi ekosistem terumbu karang dan ikan karang. Kecerahan perairan juga menggambarkan tingkat sedimentasi yang terjadi di sekitar kawasan (Ketjulan, 2010).

Kecerahan perairan di perairan Tulamben berkisar antara $87 \%-90 \%$ pada kedalaman 5 meter dan 43,5\%-57,5\% pada kedalaman 10 meter (Lampiran 3). Pada stasiun 1 kecerahan perairan diperoleh sebesar $88 \%$ dan mendapatkan skor 2, stasiun 2 diperoleh nilai kecerahan perairan sebesar $43,5 \%$ dan mendapatkan skor 1 , stasiun 3 diperoleh nilai kecerahan sebesar 90\% dan mendapatkan skor 2, stasiun 4 nilai kecerahan diperoleh sebesar 57,5\% dan mendapatkan skor 2, stasiun 5 nilai kecerahan diperoleh sebesar $87 \%$ dan mendapatkan skor 2, sedangkan stasiun 6 diperoleh nilai kecerahan sebesar $52 \%$, skor yang diperoleh adalah 2 (Tabel 6).

\subsection{Kesesuaian Wisata Snorkeling}

Kesesuaian wisata bahari kategori wisata snorkeling mempertimbangkan beberapa parameter dengan 4 klasifikasi penilaian. Parameter tersebut adalah kecerahan perairan, tutupan komunitas karang, jenis bentuk pertumbuhan, jenis ikan karang, kecepatan arus dan kedalaman terumbu karang. Kategori kesesuaian wisata snorkeling di Perairan Tulamben termasuk ke dalam kategori tidak sesuai (N) hingga sesuai (S2). Persentase kategori sesuai (S2) terdapat pada stasiun 3 dan 5, tertinggi pada stasiun 3 dengan IKW sebesar $74,07 \%$. Kategori tidak sesuai $(\mathrm{N})$ terdapat di stasiun 1 Shipwreck dengan persentase 38,89\% (Tabel 7).

Pada stasiun 1 nilai indeks kesesuaian wisata (IKW) diperoleh sebesar 38,89\%. Berdasarkan kriteria kesesuaian wisata snorkeling, nilai tersebut termasuk dalam kriteria tidak sesuai $(\mathrm{N})$. Hal ini disebabkan tutupan komunitas karang pada stasiun ini yang mendapatkan skor nol. Sementara parameter jenis bentuk pertumbuhan dan jenis ikan karang pada stasiun 1 mendapatkan

Tabel 6

Parameter- parameter dalam penentuan kesesuaian wisata selam dan snorkeling di perairan Tulamben

\begin{tabular}{ccccccc}
\hline Stasiun & Kecerahan (\%) & $\begin{array}{c}\text { Kecepatan } \\
\text { Arus (cm/dt) }\end{array}$ & $\begin{array}{c}\text { Tutupan } \\
\text { Komunitas } \\
\text { Karang }(\%)\end{array}$ & $\begin{array}{c}\text { Jumlah Jenis } \\
\text { bentuk } \\
\text { pertumbuhan }\end{array}$ & $\begin{array}{c}\text { Jenis Ikan } \\
\text { Karang }\end{array}$ & $\begin{array}{c}\text { Kedalaman } \\
\text { Karang (m) }\end{array}$ \\
\hline 1 & 88 & 13 & 16,26 & 6 & 16 & 5 \\
2 & 43.5 & 14 & 29,58 & 11 & 11 & 10 \\
3 & 90 & 13 & 52,48 & 14 & 39 & 5 \\
4 & 57.5 & 13 & 42,24 & 15 & 32 & 5 \\
5 & 87 & 15 & 25,64 & 11 & 28 & 10 \\
6
\end{tabular}




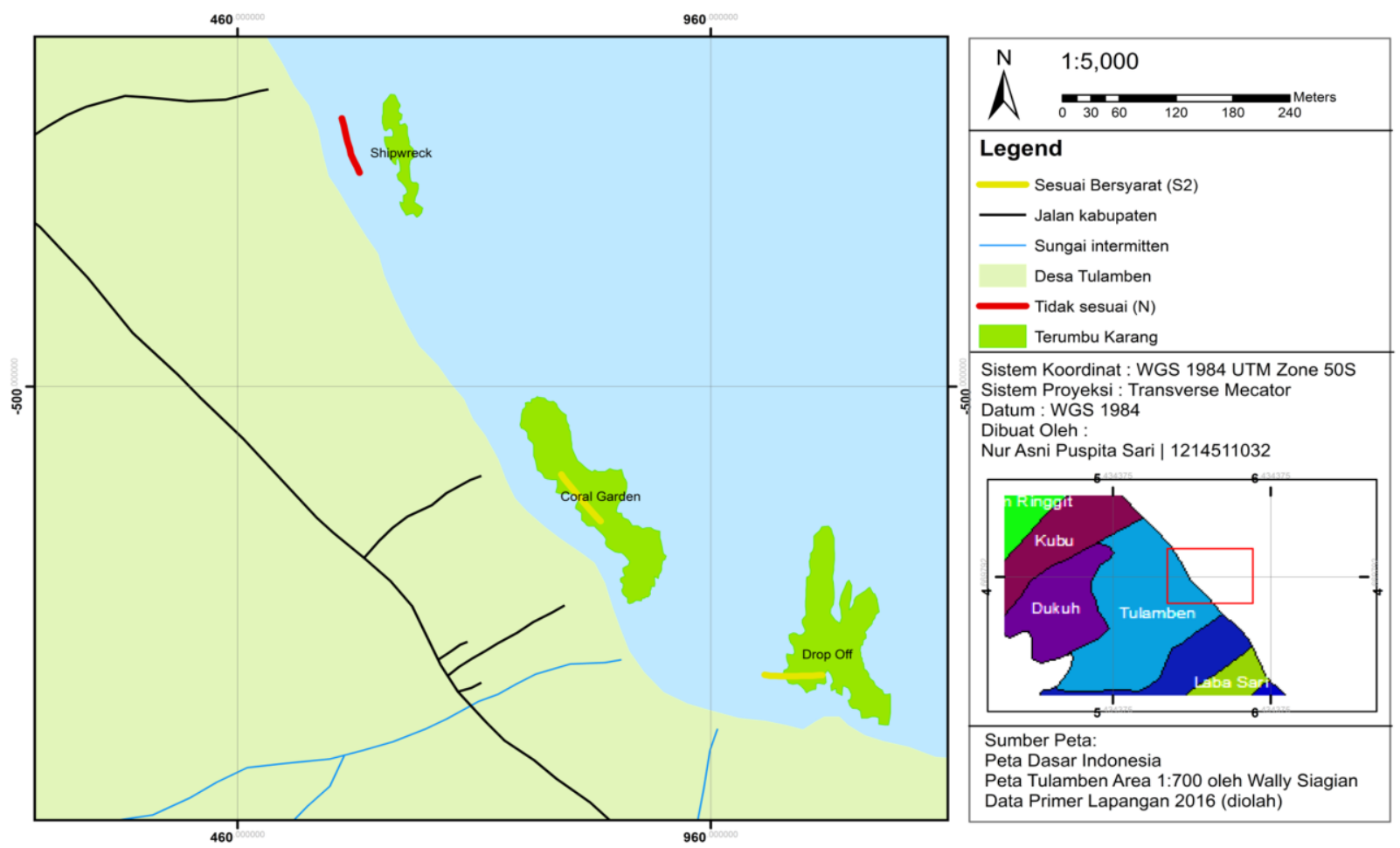

Gambar 19. Peta kesesuaian wisata snorkeling di kawasan penelitian

skor 1. Parameter yang mendukung di stasiun 1 adalah kecepatan arus, kecepatan arus di stasiun 1yang mendapatkan skor 3, parameter lainnya yaitu kecerahan perairan dan kedalaman terumbu karang mendapatkan skor 2.

\section{Tabel 7}

Indeks kesesuaian wisata snorkeling pada setiap stasiun pengamatan di Perairan Tulamben

\begin{tabular}{lccc}
\hline Lokasi & Stasiun & $\begin{array}{c}\text { Indeks } \\
\text { Kesesuaian } \\
\text { Wisata (IKW) }\end{array}$ & $\begin{array}{c}\text { Keterang- } \\
\text { an }\end{array}$ \\
\hline $\begin{array}{l}\text { Ship- } \\
\text { wreck }\end{array}$ & 1 & 38,89 & $\begin{array}{c}\text { Tidak } \\
\text { Sesuai (N) }\end{array}$ \\
$\begin{array}{l}\text { Coral } \\
\text { Garden } \\
\text { Drop Off }\end{array}$ & 3 & 74,07 & $\begin{array}{c}\text { Sesuai (S2) } \\
\text { S }\end{array}$ \\
\hline
\end{tabular}

Nilai IKW pada stasiun 3 diperoleh sebesar $74,07 \%$. Berdasarkan kriteria kesesuaian wisata snorkeling, nilai tersebut termasuk dalam kriteria sesuai (S2). Faktor pendukung pada stasiun ini yaitu jenis bentuk pertumbuhan dan kecepatan arus yang mendapatkan skor 3 dan mempunyai bobot yang besar. Sementara faktor lainnya yaitu kecerahan perairan, tutupan komunitas karang, jenis ikan karang dan kedalaman terumbu karang mendapatkan skor 2.

Kawasan Drop Off dalam kriteria kesesuaian wisata snorkeling termasuk dalam kategori Sesuai (S2) dengan nilai IKW yang diperoleh sebesar $59,26 \%$. Faktor pendukung pada stasiun ini yaitu kecepatan arus yang mendapatkan skor 3. Faktor lainnya yaitu kecerahan perairan, jenis bentuk pertumbuhan, jenis ikan karang, dan kedalaman terumbu karang mendapatkan skor 2, sedangkan faktor pembatas pada stasiun ini yaitu tutupan komunitas karang yang mendapatkan skor 3 .

\subsubsection{Kesesuaian Wisata Selam}

Parameter-parameter yang dikaji untuk menentukan kesesuaian suatu kawasan wisata bahari sebagai lokasi selam ada beberapa kategori menurut Yulianda (2007) dalam Widikurnia (2016) yaitu diantaranya kecerahan perairan, tutupan komunitas karang, jenis bentuk pertumbuhan jenis ikan karang, kecepatan arus dan kedalaman terumbu karang.

Kategori kesesuaian wisata selam di Perairan Tulamben termasuk ke dalam kategori tidak sesuai (N) hingga sesuai (S2). Persentase kategori sesuai (S2) tertinggi pada Stasiun Coral Garden dengan IKW sebesar 61,12\% sedangkan kategori tidak sesuai $(\mathrm{N})$ terdapat di stasiun Shipwreck dengan 

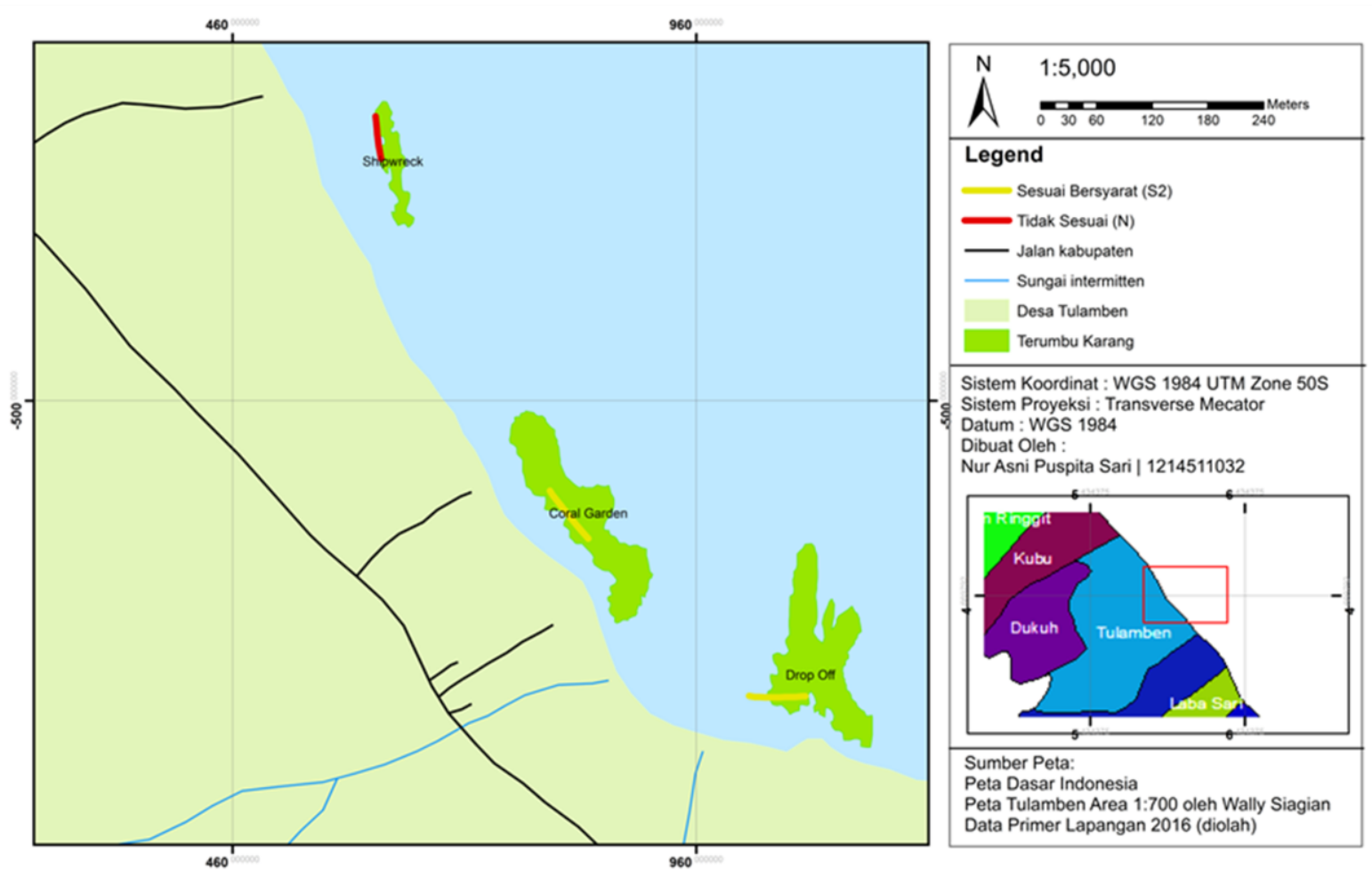

Gambar 19. Peta kesesuaian wisata snorkeling di kawasan penelitian

persentase 40,74\% (Tabel 8). Perbedaan kategori kesesuaian wisata tersebut didapatkan karena nilai kesesuaian dari setiap potensi sumberdaya berbeda untuk kegiatan wisata selam. Kategori sesuai (S2) mengindikasikan bahwa masih terdapat beberapa faktor kesesuaian wisata yang tergolong minim dan menjadi faktor pembatas pada stasiun yang tergolong S2 (Adi et al., 2013).

\section{Tabel 8}

Indeks kesesuaian wisata selam pada setiap stasiun pengamatan di Perairan Tulamben

\begin{tabular}{lccc}
\hline \multicolumn{1}{c}{ Lokasi } & Stasiun & $\begin{array}{c}\text { Indeks } \\
\text { Kesesuaian } \\
\text { Wisata } \\
(\mathrm{IKW})\end{array}$ & $\begin{array}{c}\text { Keterang- } \\
\text { an }\end{array}$ \\
\hline Ship-wreck & 2 & 40,74 & $\begin{array}{c}\text { Tidak } \\
\text { Sesuai (N) }\end{array}$ \\
$\begin{array}{l}\text { Coral } \\
\text { Garden } \\
\text { Drop Off }\end{array}$ & 4 & 61.12 & Sesuai (S2) \\
\hline
\end{tabular}

Pada stasiun 2 nilai indeks kesesuaian wisata (IKW) diperoleh sebesar 40,74 \%. Berdasarkan kriteria kesesuaian wisata selam, nilai tersebut termasuk dalam kriteria tidak sesuai $(\mathrm{N})$. Faktor pembatas pada stasiun ini yaitu jenis ikan karang karang yang mendapatkan skor nol. Sementara parameter kecerahan perairan dan tutupan komunitas karang pada stasiun 2 mendapatkan skor 1, skor yang didapat untuk kedua parameter ini bernilai kecil. Parameter yang mendukung di stasiun 2 adalah kecepatan arus dan kedalaman terumbu karang, kedua parameter ini mendapatkan skor 3 .

Nilai IKW pada stasiun 4 diperoleh sebesar $61,11 \%$. Berdasarkan kriteria kesesuaian wisata selam, nilai tersebut termasuk dalam kriteria sesuai (S2). Faktor pendukung pada stasiun ini yaitu jenis bentuk pertumbuhan, kedalaman terumbu karang dan kecepatan arus yang mendapatkan skor 3 dan mempunyai bobot yang besar. Sementara faktor lainnya yaitu kecerahan perairan mendapatkan skor 2. Adapun faktor pembatas di kawasan ini yaitu tutupan komunitas karang dan jenis ikan karang yang mendapat skor 1.

Kawasan Drop Off dalam kriteria kesesuaian wisata selam termasuk dalam kategori Sesuai (S2) dengan nilai IKW yang diperoleh sebesar 55,56\%. Faktor pendukung pada stasiun ini yaitu kecepatan arus dan kedalaman terumbu karang yang mendapatkan skor maksimum. Faktor lainnya yaitu kecerahan perairan dan jenis bentuk pertumbuhan mendapat skor 2, sedangkan faktor pembatas pada stasiun ini yaitu tutupan 
komunitas karang dan jenis ikan karang yang mendapatkan skor rendah.

\section{Simpulan}

Kondisi terumbu karang di kawasan Perairan Tulamben termasuk dalam kategori rusak hingga baik dimana persentase tutupan karang sebesar 16,26\%-52,48\%. Kondisi rusak terdapat di Shipwreck kedalaman 5 meter, kondisi sedang berada di Shipwreck kedalaman 10 meter, Coral Garden kedalaman 10 meter dan Drop off. Coral Garden kedalaman 5 meter termasuk dalam kategori baik. Pada pengamatan dijumpai sebanyak 100 jenis ikan karang yang termasuk dalam 25 suku. Kondisi lingkungan perairan dilihat dari kedalaman, kecepatan arus dan kecerahan perairan Tulamben tergolong baik untuk pertumbuhan karang. Hasil analisis kesesuaian wisata snorkeling menunjukkan, dari 3 dive site yang sering dikunjungi wisatawan, stasiun 1 yang berlokasi di Shipwreck termasuk dalam kategori $\mathrm{N}$ atau tidak sesuai untuk kawasan wisata snorkeling dengan nilai 38,89 sedangkan Coral Garden dan Drop Off termasuk dalam kategori S2 atau sesuai sebagai kawasan wisata snorkeling dengan masing-masing nilai sebesar 74,07 dan 59,26 . Hasil yang sama ditunjukkan pada kesesuaian wisata selam, dimana Coral Garden dan Drop Off sesuai untuk kegiatan wisata selam dengan nilai masing-masing 61,11 dan 55,56 sedangkan Shipwreck mendapatkan nilai sebesar 40,74 yang artinya tidak sesuai untuk kegiatan wisata selam.

\section{Ucapan terimakasih}

Terima kasih penulis ucapkan kepada Navila Fauziyanti (Mahasiswi Jurusan Geografi UGM) yang telah membantu dalam pengambilan data, Mapala Wanaprastha Dharma Universitas Udayana dan semua pihak yang telah membantu penelitian ini.

\section{Daftar Pustaka}

Adi AB, Mustafa A, Ketjulan R. (2013). Kajian potensi kawasan dan kesesuaian terumbu karang di Pulau Lara untuk pengembangan ekowisata bahari. Jurnal Mina Laut Indonesia, 1(1), 49-60.

Adrim M, Harahap SA, Wibowo K. (2012). Struktur komunitas ikan karang di perairan Kendari. Ilmu Kelautan 17(3), 154-163.
Bato M. (2013). Kajian manfaat kawasan konservasi perairan bagi pengembangan ekowisata bahari : studi kasus di kawasan konservasi perairan Nusa Penida, Bali. Depik, 2(2), 104-113.

Haruddin A, Purwanto E, Budiastuti S. (2011). Dampak kerusakan ekosistem terumbu karang terhadap hasil penangkapan ikan oleh nelayan secara tradisional di Pulau Siampu Kabupaten Buton Provinsi Sulawesi Tenggara. Jurnal Ekosains, 3(3), 29-41.

Hasler H, Ott JA. (2008). Diving down the reefs? Intensive diving tourism threatens the reef of the northern Red Sea. Marine Pollution, 56, 1788-1794.

Juliana. (2013). Kesesuaian dan daya dukung wisata bahari di perairan Bandengan Kabupaten Jepara Jawa Tengah. Jurnal Perikanan dan Kelautan Tropis, 9(1), 1-7.

Ketjulan R. (2011). Daya dukung perairan Pulau Hari sebagai obyek ekowisata bahari. Jurnal Aqua Hayati, 7(3), 183-188.

Leonard O. (2014). Kesesuaian perairan untuk wisata selam dan snorkeling di Pulau Biawak, Kabupaten Indramayu. Journal of Marine Research, 3(3), 216-225.

Rajab MA. (2013). Daya dukung perairan Pulau Liukang Loe untuk aktivitas ekowisata bahari. Depik, 2(3), 114-125.

Salsabiela M, Anggoro S, Hartuti P. (2014). Kajian keefektifan pengelolaan terumbu karang (studi kasus: Kawasan Konservasi Laut Daerah Pulau Biawak dan sekitarnya, Kabupaten Indramayu). Saintek Perikanan, 10(1), 13-18.

Suryanti. (2011). Kondisi terumbu karang dengan indicator ikan chaetodontidae di Pulau Sambangan Kepulauan Karimun Jawa, Jepara, Jawa Tengah. 56Oseanografi Marina, 1(1), 106-119.

Taofiqurohman A. (2013). Penilaian tingkat risiko terumbu karang akibat dampak aktivitas penangkapan ikan dan wisata bahari di Pulau Biawak, Jawa Barat. Depik, 2(2), 50-57.

Tomboelu N, Bengen DG, Nikijuluw VPH, Idris I. (2000). Analisis kebijakan pengelolaan sumberdaya terumbu karang di kawasan Bunaken dan sekitarnya. Jurnal Pesisir dan Lautan, 3(1), 51-67.

Trialfhianty TI. (2013). Kondisi Terumbu Karang dan Ikan Karang Perairan Tulamben Bali. Skripsi. Yogyakarta : Jurusan Manajemen Sumber Daya Perikanan Universitas Gadjah Mada.

Widikurnia P. (2016). Pengelolaan Ekosistem Terumbu Karang untuk Kegiatan Ekowisata Selam di Pulau Biawak, Indramayu, Jawa Barat. Skripsi. Bogor, Indonesia: Departemen Manajemen Sumber Daya Perairan Fakultas Perikanan dan Ilmu Kelautan Institut Pertanian Bogor.

Zulfikar. (2011). Kesesuaian dan daya dukung ekosistem terumbu karang sebagai kawasan wisata selam dan snorkeling di Tuapejat Kabupaten Kepulauan 
Indonesia, 17(1), 195-203.

(C) 2017 by the authors; licensee Udayana University, Indonesia. This article is an open access article distributed under the terms and conditions of the Creative Commons Attribution license (http://creativecommons.org/licenses/by/3.0/). 